Paideusis

\title{
Dissimilarities Between Deweyan Pragmatism and Confucianism
}

\section{Russell Shen}

Volume 20, Number 1, 2012

URI: https://id.erudit.org/iderudit/1071841ar

DOI: https://doi.org/10.7202/1071841ar

See table of contents

Publisher(s)

Canadian Philosophy of Education Society

ISSN

0838-4517 (print)

1916-0348 (digital)

Explore this journal

Cite this article

Shen, R. (2012). Dissimilarities Between Deweyan Pragmatism and Confucianism. Paideusis, 20(1), 24-32. https://doi.org/10.7202/1071841ar
Article abstract

Over the past decade, numerous Deweyan philosophers have been arguing that Deweyan Pragmatism and Confucianism have significantly similar philosophical underpinnings and thus a Deweynised Confucian society is highly plausible. This article examines the social and historical backdrops against which Deweyan and Confucian thoughts were developed. It then explores the starkly contrasting and oftconflicting views of Dewey and Confucius on the purpose of education, the curriculum in schools, and the respective roles of teachers and students, morality, individuality, sociality as well as politics. The conclusion of this paper is that Deweyan Pragmatism is a context-specific, anti-dualist, and egalitarian theory whereas Confucianism is a transcendental virtue-oriented, universalist, and elitist philosophy. Therefore, any effort to promote the co-optation of Confucianism in Deweyan applications within Confucian civilisations, no matter how well intentioned, blocks the path to truth.
This document is protected by copyright law. Use of the services of Erudit (including reproduction) is subject to its terms and conditions, which can be viewed online.

https://apropos.erudit.org/en/users/policy-on-use 
Paideusis, Volume 20 (2012), No. 1, pp. 24-32

\title{
Dissimilarities Between Deweyan Pragmatism and Confucianism
}

\author{
RUSSELL SHEN \\ Queen's University, Kingston, Ontario, Canada
}

\begin{abstract}
Over the past decade, numerous Deweyan philosophers have been arguing that Deweyan Pragmatism and Confucianism have significantly similar philosophical underpinnings and thus a Deweynised Confucian society is highly plausible. This article examines the social and bistorical backdrops against which Deweyan and Confucian thoughts were developed. It then explores the starkly contrasting and oftconflicting views of Dewey and Confucius on the purpose of education, the curriculum in schools, and the respective roles of teachers and students, morality, individuality, sociality as well as politics. The conclusion of this paper is that Deweyan Pragmatism is a context-specific, anti-dualist, and egalitarian theory whereas Confucianism is a transcendental virtue-oriented, universalist, and elitist philosophy. Therefore, any effort to promote the co-optation of Confucianism in Deweyan applications within Confucian civilisations, no matter how well intentioned, blocks the path to truth.
\end{abstract}

In recent years, there has been a spate of papers and books asserting the similarities and compatibilities between Deweyan Pragmatism and Confucianism. In this article, I argue that the purported affinities between these two schools of philosophy are specious at best. Even though not exactly antithetical on all points, they are drastically different in their discourses on education, morality, politics, and on the relationship between individuality and sociality.

\section{Literature Review}

The stream of publications highlighting the "affinity between John Dewey's Pragmatism and Confucianism" (Tan, 2003, p. 141) has been steady and influential over the past decade. For example, with respect to epistemology, Grange (2004) argues that:

Way is the conventional translation of the Chinese word dao. Exploring its depth of meaning is fundamental to grasping a real understanding of the Confucian sense of reality. I claim that it is the Confucian equivalent of Dewey's primary concept of experience. (p. 23)

Also, Grange writes:

I suggest that a primary working connection between Dewey and Confucius is to be found in the concept of $l i$ (observing ritual propriety). It is to be understood as the equivalent of the felt intelligence that grounds Dewey's concept of inquiry. (p. 50)

(C) Copyright 2012. The author, Russell Shen, assigns to Paideusis the right of first publication and educational and non-profit institutions a non-exclusive license to use this document for personal use and in courses of instruction provided that the article is used in full and this copyright statement is reproduced. Any other usage is prohibited without the express permission of the author. 
As for morals, Sim (2009) notes that "not only do Confucius and Dewey agree that moral education leads to an expanded self, both also agree that the self is not a fixed substance but is relational and in the process of formation" (p. 86).

Concerning the relationship between individuality and sociality, Tan (2004) claims that Dewey's conceptualization of self as associated living is in conformity with the Confucian sensitivity to the social roots of every human being. Similarly, Grange (2004) thinks that the whole thrust of Confucianism is to bridge the separation between the social order and the aims of the individual. Its parallels with Dewey should be obvious.

Regarding political orientations, Tan (2003) contends, "in a Confucian ethico-political order, as in a Deweyan democracy, questions about conceptions of the good that should guide social and political actions are resolved in cooperative inquiry" (p. 202). Hall and Ames (1999) go so far as to argue that Dewey's conception of communitarian democracy is the best bridge between Confucian civilization and a democratic future.

\section{Contrasting Socio-Historical Backdrops}

The fundamental differences between the theories of these two philosophers are deeply rooted in the socio-historical backgrounds of their lives. Three generations of Dewey's forbearers were farmers in Vermont and both of his parents were raised there. These forbearers had characteristics typical of early New Englanders: industriousness, self-reliance, little pretense, and independent thinking. More importantly, Dewey himself had opportunities unusual for a child growing up in a Vermont village in the 1860s. He had contact with diverse cultures due to the fact that the population in the community of Burlington was culturally mixed. "The association with boys and girls of cultural and income groups quite different from his own undoubtedly provided liberalizing influences [on Dewey]" (Dykhuizen, 1973, p. 3). During his development as a thinker, he was active and often rebellious in an era of massive social integration, urbanization, industrialization, and economic centralization (Campbell, 1995).

Dewey's own intellectual struggle for liberalization can been seen as a symbol of cultural and social change which at every point in twentieth-century history have been in conflict with institutional dogmas and new forms of authoritarian thinking. (Dykhuizen, 1973, p. xxii).

In contrast, Confucius was born in $551 \mathrm{BCE}$ to a poor family of aristocracy. The world he faced was very unpromising. Along with rampant feudal anarchy, there was no higher power-neither spiritual nor temporal - to attract loyalty. Consequently, Confucius greatly admired a fabled ruler, the Duke of Zhou, for his morality and loyalty. This painfully turbulent historical background also at least partly justifies the Confucian conservatism, embodied by a series of famous dicta such as "The ruler must rule, the minister minister, the father father, and the son son" (The Analects, hereinafter AN, 12.11). ${ }^{1}$ Confucius himself was, poignantly, the living proof of the Deweyan belief that, "Order cannot but be admirable in a world constantly threatened with disorder-in a world where living creatures can go on living only by taking advantage of whatever order exists about them, incorporating into themselves" (LW 10:20). ${ }^{2}$

\footnotetext{
${ }^{1}$ Unless otherwise stated, all references to Confucius are from The Analects of Confucius: A Philosophical Translation, translated by Roger T. Ames and Henry Rosemont, Jr.. New York, NY: Ballantine Books, 1998.

2 All references to Dewey are from The Collected Works of John Dewey, 1882-1953. (Electronic Edition), edited by Larry A. Hickman. Charlottesville, VA: InteLex Co., 2003. EW, MW, and LW refer to The Early Works of John Dewey, 1882-1898 (5 volumes), The Middle Works of John Dewey, 1899-1924 (15 volumes) and The Later Works of John Dewey, 1925-1953 (17 volumes).
} 


\section{Opposite Views on Education}

In spite of some superficial similarities between the Confucian pedagogy and Deweyan pedagogy, I would argue that their educational theories run counter to each other in the following three aspects: the purpose of education, the curriculum, and the respective roles of teachers and students.

\section{On the Purpose of Education}

Dewey believes learning requires a reflective and critical understanding of one's purposes (Rockefeller, 1991), which are intrinsically associated with the diagnosis of the problems one faces: "Without a problem, there is blind groping in the dark" (LW 12:112). It is clear that Dewey's understanding of the learning experience is always specific to the problem that one confronts. Moreover, Dewey believes that learning should involve continual interaction between learners and the objectives they attempt to achieve:

A man does something; he lifts, let us say, a stone. In consequence he undergoes, suffers, something: the weight, strain, texture of the surface of the thing lifted. The properties thus undergone determine further doing. The stone is too heavy or too angular, not solid enough; or else the properties undergone show it is fit for the use for which it is intended. The process continues until a mutual adaptation of the self and the object emerges and that particular experience comes to a close. (LW 10:50)

This can also be verified with Dewey's adherence to ends that are "experimental and hence constantly growing as it is tested in action" (MW 9:112). In the context of education, he stresses the reconstructive nature of each learning experience because there is always the precarious, the unstable, and the unsettled in our experience of the world:

We are always dependent upon the experience that has accumulated in the past and yet there are always new forces coming in, new needs arising, that demand, if the new forces are to operate and the new needs to be satisfied, a reconstruction of the patterns of old experience. (LW 11:36)

Further, Dewey believes that any past and current knowledge is a hypothesis for the future and therefore must be empirically tested when it is applied in a new setting:

The old and the new have forever to be integrated with each other, so that the values of old experience may become the servants and instruments of new desires and aims ... Every problem that arises, personal or collective, simple or complex, is solved only by selecting material from the store of knowledge amassed in past experience and by bringing into play habits already formed. But the knowledge and the habits have to be modified to meet the new conditions that have arisen ... The standing danger is either that they will be acted upon implicitly, without reconstruction to meet new conditions, or else that there will be an impatient and blind rush forward, directed only by some dogma rigidly adhered to. (LW 11:36-37)

In addition to his conviction that acquired knowledge should be empirically tested, Dewey asserts that:

It is its [education's] business to cultivate deep-seated and effective habits of discriminating tested beliefs from mere assertions, guesses and opinions; to develop a lively, sincere, and open-minded preference for conclusions that are properly grounded, and to ingrain into the individual's working habits methods of inquiry and reasoning appropriate to the various problems that present themselves. (MW 6:202) 
All of this considered, we should find it easy to grasp the two-fold purpose of Dewey's Laboratory School: (1) to exhibit, test, verify and criticize theoretical statements and principles; and (2) to add to the sum of facts and principles in its special line.

Nevertheless, for Dewey schools are not mere testing grounds for intellectual inquiry. They also have important moral and ethical purposes: "Upon the ethical side, the tragic weakness of the present school is that it endeavors to prepare future members of the social order in a medium in which the condition of the social spirit are eminently waiting" (MW 1:10). Dewey argues that if the qualities of mind are developed under conditions where their social significance is realized, they feed moral interest and develop moral insight. Consequently, he suggests that schools should meet the following requirements as well: "(i) In the first place, the school must itself be a community life in all which that implies ... [and] (ii) The learning in school should be continuous with that out of school. There should be a free interplay between the two" (MW 9:368). As for the validity of knowledge, Dewey emphasizes that only through a community of investigators can we know reality rationally (Rockefeller, 1991).

Like Dewey, Confucius also recognizes the possibility of encountering uncertainty and precariousness in learning. His aversion to them, however, is apparent: "If you listen broadly, set aside what you are unsure of, and speak cautiously of the rest, you will make few mistakes. If you look broadly, set aside what is perilous, and act cautiously on the rest, you will have few regrets" (AN 2.18).

For Confucius, ends are not the Deweyan "satisfactions" that emerge temporarily in the process of problem-solving; they are prescribed by the $l i$ and by a heaven-given xing (Sim, 2009). The ultimate purpose of learning is to grasp the $W$ ay: "If at dawn you learn of and tread the Way, you can face death at dusk" (AN 4.8). Specifically, in his dialogues with his disciples, Confucius puts forth "the $W$ ay of the Former Kings" (AN 1.12), "the Way of the Master" (AN 4.15) and "the Way of the Heaven" (AN 17.19), all of which are essentially transcendent ideals that do not require experiments. Moreover, for Confucius, the social significance of education and its moral purpose are separable: "In eating, exemplary persons (jun₹l) do not look for a full stomach, nor in their lodgings for comfort and contentment ... Such persons can indeed be said to have a love of learning" (AN 1.14).

An education system in which learners are supposed to be entirely free from basic biological and economic needs can hardly be regarded as moral in the Deweyan conception of the school as "a form of social life, a miniature community and one in close interaction with other modes of associated experience beyond school walls" (MW 9:370). The burden is thus on Confucian-Deweyans like Tan, Ames, Hall and Grange to explain the following statement from Dewey:

Because of the influence of a low view of human nature and of matter a sharp line has been drawn and become generally current between what is called economic and what is called moral—and this in spite of facts which demonstrate that at present industry and commerce have more influence upon the actual relation of human groups to one another than any other single factor. (LW 15:60)

\section{On the Curriculum}

Dewey believes that "No matter what the present success in straightening out difficulties and harmonizing conflicts, it is certain that problems will recur in the future in a new form or on a different plane" (MW 14:197). His ideals about the curriculum are thus very skill-oriented as opposed to knowledge-oriented. His understanding of an effective history course is indeed very similar to historiographic research that involves helping students explore the driving forces behind the industrial, cultural or intellectual development of a society. Dewey's idea of the geography course is essentially a socially, economically or politically-oriented analysis of geographical facts and his conception of vocational education is geared toward what students will need in the future. His objectives for moral education are more concerned with the cultivation of open-mindedness, intellectual honesty, and a sense of responsibility (Clopton and $\mathrm{Ou}, 1973$ ). 
In sharp contrast, although Confucius does not deny the importance of learning about new situations, he suggests that sometimes the same problems are recurring. As such, he believes that solutions to these problems should be found: "The Master said: 'Having studied, to then repeatedly apply what you have learned-is this not a source of pleasure?" " (AN 1.1). Confucius is well known for his love of antiquity: "I am not the kind of person who has gained knowledge through some natural propensity for it. Rather, loving antiquity, I am earnest in seeking it out" (AN 7.20). Specifically, he attaches great importance to the study of five ancient classics, which are, in the order in which they are usually discussed in his classes, the Classic of Changes, the Classic of Documents, the Classic of Songs, the Record of Rituals and the Spring and Autumn Annals (Stavrianos, 1975).

As for art education, Dewey thinks of art as "the most universal and freest form of communication" (LW 10:275), whereas Confucius regards it as a source of precepts for people to follow: "If people can recite all of the three hundred Songs and yet when given official responsibility, fail to perform effectively ... then even though they have mastered so many of them [the Songs], what good are they to them?" (AN 13.5).

\section{On the Roles of Teachers and Students}

In line with his conception of the purpose of education, Dewey's view of a teacher is a facilitator of learning who should try to discern and make adjustments to the child's needs:

What concerns him, as a teacher, is the ways in which that subject may become a part of experience; what there is in the child's present that is usable with reference to it; how such elements are to be used; how his own knowledge of the subject-matter may assist in interpreting the child's needs and doings, in order that his growth may be properly directed (MW 2:286).

For Confucius, a successful teacher is the ultimate role model for students and deserves reverence. This famous passage from the Analects depicts a transcendental super-teacher who readers would feel obligated to deify:

The Master said: "From fifteen, my heart-and-mind was set upon learning; from thirty I took my stance; from forty I was no longer doubtful; from fifty I realized the propensities of Heaven; from sixty my ear was attuned; from seventy I could give my heart-and-mind free rein without overstepping the boundaries. (AN 2.4)

His ideal regarding a super-teacher's role was fulfilled posthumously (Hucker, 1978). To the later generations of Chinese, "he is the 'model teacher of ten thousand generations" "(Tan, 2007, p. 148).

\section{Differing Views on Morality}

Dewey's understanding of morality is anti-dualist, fluid and organic. For Dewey, morality cannot be judged without context because he interprets human nature as "something moving, changing, discrete, and above all initiating instead of final" (LW 1:167). He also rejects the view of will being "a power of choosing, having no ground or reason outside the arbitrary choice itself which isolates the moral agent from all social relations" (LW, 7:341). As a result, Dewey believes that there is no fixed list of virtues. Virtues are numberless and change with time and custom.

Another reason for the necessity of ongoing moral judgment is that we live in a time which brings with it "moral unsettlement and tends to destroy many ties which were the chief safeguards of the morals of custom" (LW 7:177). Moreover, Dewey is vehemently against unthinking, knee-jerk or moralistic goodness: "Only deliberate action, conduct into which reflective choice enters, is distinctively 
moral, for only then does there enter the question of better and worse" (MW 14:193). For him, all morals are social issues and he sees moral development as an expansion of one's ends and the reconstruction of one's character.

Everyone is a social being who occupies various social positions that call for certain modes of action. These actions lead us to still further roles ... Growth occurs when desire and duty conflict, and when habits which form one's so-far settled character conflict with desirable but nascent tendencies. For Dewey, the tension between a settled past and a pregnant future is a creative tension. (Sim, 2009, p. 86)

Dewey resolves the conflict between interest and duty in the following manner: First, he offers a self that is not "ready-made" but is "in continuous formation through choice of action". Second, he puts forth a more intimate and less instrumental relationship between "self" and "interest." Third, he offers a comparably flexible sense of self-interest so that risking one's life is not "disinterested" but an act with which the self has come to identify (Sim, 2009).

Confucius sees moral development as the conformity to a set of transcendental, eternal virtues such as ren and a set of prescribed rules, such as $l i$, which are either from exemplary people living in antiquity or from Heaven and are substantive purposes to strive for. For example, he exclaimed, "How great indeed was Yao as ruler! Only tian (heaven) is truly great and only Yao took it as his model ... How majestic was he in his accomplishments, and how brilliant was he in his cultural achievements" (AN 8.19).

As for moral action, Confucius emphasizes two aspects: First, it should be virtuous, conforming to $l i$. Second, the agent must be modest and sincere in his or her performance (Sim, 2009, p. 89). For instance, the Master says, "Those today who are filial are considered so because they are able to provide for their parents. But even dogs and horses are given that much care. If you do not respect your parents, what is the difference?" (AN 2.7). Confucian morality sometimes seems de-contextualized. For example:

The Governor of She in conversation with Confucius said, "In our village there is someone called 'True Person'. When his father took a sheep on the sly, he reported him to the authorities." Confucius replied, "Those who are true in my village conduct themselves differently. A father covers for his son, and a son covers for his father." (AN 13.18)

Interestingly, the following statement made by Dewey sounds as if it is directed right at Confucius: "Is there not something strange in the fact that men should consider loyalty to 'laws' principles, standards, ideals to be an inherent virtue, accounted onto them for righteousness?" (LW 4:222)

Duty and material interest in Confucian thought are frequently seen as mutually exclusive, evidenced in clear-cut statements like:

Exemplary persons cherish their excellence; petty persons cherish their land. Exemplary persons cherish fairness; petty persons cherish the thought of gain. (AN 4.11)

and:

If on seeing a chance to profit they think of appropriate conduct (li), on seeing danger they are ready to give their lives, and when long in desperate straits, they still do not forget the words they live by - such persons can also be said to be consummate. (AN 14.12) 


\section{Individuality Versus Sociality}

The Deweyan conception of self is "essentially social being constituted not by isolated capacity, but by capacity acting in response to the needs of an environment-an environment which, when taken in its fullness, is a community of persons" (EW 3:335). Similarly, his understanding of human nature is that we are all social creatures whose identities and fulfillment are grounded in communal participation (Campbell, 1995).

On the other hand, Dewey does not fail to stress the importance of asserting individuality in communal life: "To learn to be human is to develop through the give-and-take of communication an effective sense of being an individually distinctive member of a community" (LW 2:332). Dewey adheres to the requirement that inquiry be public. An inquirer's claim to have successfully resolved an indeterminate situation should be checked by others. In fact, he bases his deconstruction of traditional metaphysics on its very failure to have such publicly testable consequences (Gale, 2010, p. 32).

Qi (2008) suggests that the construction of the Confucian self is for the sake of community order, which is not achieved through mutual adjustment between the community and its individual members, but through the focus on the preservation of the community hierarchy. In The Analects of Confucius: A Pbilosophical Translation, Ames and Rosement (1998) also acknowledge that "in promoting the family as the pervasive model of order, the Confucian worldview does not accept that hierarchical social institutions are necessarily pernicious, or that simple egalitarianism should be an uncritical value" (p. 77).

\section{Conflicting Political Views}

The premise for comparing the political thoughts of Dewey and those of Confucius may be somewhat questionable. After all, Dewey's political theories have never been carried out, not even during his stay in China when he met with many Chinese political leaders, including Sun Yat-sen, the foremost leader of the Chinese revolution that ended the last feudal dynasty (Su, 1995). Confucian thoughts on politics may be even harder to evaluate accurately because "since its establishment as the orthodoxy of the Chinese empire in the Han Dynasty, Confucianism frequently has been misappropriated by those in power for their own selfish interests at the expense of those they ruled so much so that many have viewed those distortions as constituting Confucianism itself" (Tan, 2003, p. 7). Even so, comparisons confined to purely theoretical levels still reveal substantial differences between the two schools of philosophy.

The Deweyan understanding of a democratic system clearly emphasizes respect for and upholding of the welfare of all its members. "If democracy has a moral and ideal meaning, it is that a social return be demanded from all and that opportunity for development of distinctive capacities be afforded to all" (MW 9:129). On the other hand, Dewey believes that the state is not just a lifeless machine for insuring personal safety and convenience. Through open inquiry and communication, citizens can learn that democracy encourages the development of the common good (Campbell, 1995). Therefore, Dewey's conception of democracy is an organic entirety within which the development of both the individual and common good are promoted through open public inquiry. As for the implementation of public policy, Dewey writes:

Every measure of policy put into operation is, logically, and should be actually, of the nature of an experiment. For (1) it represents the adoption of one out of a number of alternative conceptions as possible plans of action, and (2) its execution is followed by consequences which, while not as capable of definite or exclusive differentiation as in the case of physical experimentation, are nonetheless observable within limits, so they may serve as tests of the validity of the conception acted upon. (LW 12:502) 
Confucius advocates the rule of a set of transcendent virtues and the rule by exemplary individuals who embody these virtues: "The exemplary person's opportunity to serve in office is the occasion to effect what he judges as important and appropriate" (AN 18.7) and, "The Way of the sage is complete when he sets the world aright after having set himself aright" (Tan, 2003, p. 97). Specifically, Confucius stresses the importance of $d e$ and $l i$ in achieving and maintaining social order:

The Master said: "Lead the people with administrative injunctions and keep them orderly with penal law and they will avoid punishment but will be without a sense of shame. Lead them with excellence $(d e)$ and keep them orderly through ritual propriety $(l i)$ and they will develop a sense of shame and moreover, will order themselves." (AN 2.3)

Confucian politics tends to downplay communication between different members of society. For example, Confucius suggested that "Wise people dwelt in seclusion to pursue their ends and acted on their personal sense of importance to extend their Way" (AN 16.11) and "When the Way prevails in the empire, reveal yourself; when it does not, hide" (AN 8.13). When applied in the political arena, an existing leader's faith in "Jun zi (exemplary person) desires to be halting in speech but quick in action" (AN 4.24) may preclude political pluralism which is the very thing that necessitates political communication. A political system predicated on such a school of philosophy would be very stable indeed because without competing values, it becomes self-referential.

\section{Conclusion}

As a context-specific, anti-dualist, and egalitarian philosophy, Deweyan Pragmatism is fundamentally distinct from Confucianism, which is transcendental, virtue-oriented, universalist, and elitist. Any serious attempt to apply Deweyan Pragmatism in Confucian contexts should not discount the dissimilarities or even oppositions between these two schools of philosophy.

\section{References}

Ames, R.T. \& Rosement, H. Jr. (1998). The Analects of Confucius: A Philosophical Translation. New York, NY: Ballantine.

Campbell, J. (1995). Understanding John Dewey. Chicago, IL: Open Court.

Dewey, J. (2003). The Collected Works of John Dewey, 1882-1953. Electronic Edition. Retrieved from InteLex Past Masters.

Dykhuizen, G. (1973). The Life and Mind of John Dewey. Carbondale, IL: Southern Illinois University Press.

Gale, R.M. (2010). Jobn Dewey's Quest for Unity. Amherst, NY: Prometheus Books.

Grange, J. (2004). John Dewey, Confucius, and Global Philosophy. Albany, NY: State University of New York Press.

Hall, D., \& Ames, R. (1999). The Democracy of the Dead: Dewey, Confucius, and the Hope for Democracy in China. Chicago, IL: Open Court.

Hickman, L. A., \& Alexander, T. (1998). The Essential Dewey. (Ed.). Bloomington, IN: Indiana University Press.

Hucker, C. O. (1978). China to 1850. Stanford, CA: Stanford University Press.

Rockefeller, S. C. (1991). John Dewey: Religious Faith and Democratic Humanism. New York, NY: Columbia University Press. 
Sim, M. (2009). Dewey and Confucius: On moral education. Journal of Chinese Pbilosophy, 36(1), 86-105. Stavrianos, L. S. (1975). The World to 1500: A Global History. Eaglewood Cliffs, NJ: Prentice-Hall.

$\mathrm{Su}, \mathrm{Z}$. (1995). A critical evaluation of John Dewey's influence on Chinese education. American Journal of Education, 103, 302-322.

Tan, S. H. (2003). Confucian democracy. Albany, NY: State University of New York Press.

Tan, S. H. (2007). Confucian democracy as pragmatic experiment: Uniting love of learning and love of antiquity. Asian Philosophy, 17(2), 141-166.

Zhang, X. (2001). Whither China: Intellectual Politics in Contemporary China. Durham, NC: Duke University Press.

\section{About the Author}

Russell Shen is a M.A. student in the Faculty of Education at Queen's University. His email address is russell200912@yahoo.com. 